\section{Stimulating Asparagus Seedling Shoot Production with Benzyladenine}

\author{
Sauveur Mahotiere, Clarence Johnson ${ }^{2}$, and Philamenia Howard ${ }^{3}$ \\ Agricultural Research Station, School of Agriculture, Home Economics, and \\ Allied Programs, Fort Valley State College, Fort Valley, GA 31030-3298
}

Additional index words. Asparagus officinalis, apical dominance, correlative inhibition, cytokinins

The progressive emergence of asparagus (Asparagus officinalis L.) spears is caused by apical dominance shoot inhibition. Applied cytokinins may affect apical dominance by releasing lateral shoot buds from inhibition (Philips, 1969). Applying kinetin directly to buds induced axillary shoot stimulation in poinsettia (Euphorbia pulcherrima Willd.) (Milbocker, 1972) and branching in Kalanchoe tormentosa Bak. (Lyons and Hale, 1987). $\mathrm{N}$-(phenylmethyl)-1H-purine-6-amine (benzyladenine, BA) also released axillary apple (Malus domestica Borkh.) buds from correlative inhibition (Green and Autio, 1989). Field drenching asparagus crowns with BA at 25 and $50 \mathrm{mg} \cdot$ liter $^{-1}$ reduced spear emergence and yield (Benson, 1970). Soaking 1-year-old crowns in BA at $200 \mathrm{mg} \cdot$ liter $^{-1}$ did not affect asparagus bud inhibition (unpublished data); however, the effects of applying BA to asparagus ferns have not been reported previously.

The objective of this study was to determine the effect of foliar BA applications on shoot emergence and growth of potted asparagus seedlings outdoors.

'Mary Washington', 'UC $157 \mathrm{~F}_{1}$ ', and 'UC $157 \mathrm{~F}_{2}$ ' asparagus cultivars were grown outdoors on benches in $25 \times 25 \times 20$-cm (height and upper and lower diameters) black pots containing a 3 peatmoss : 1 perlite : 1 vermiculite (by volume) soilless medium with a $\mathrm{pH}$ of 6.2. Three seeds were planted per pot on 18 July 1990 . Seedlings were thinned to one plant per pot. During the growing period, the plants were fertilized monthly with $10 \mathrm{~g}$ of $10 \mathrm{~N}-4.5 \mathrm{P}-8.3 \mathrm{~K}$ granular formulation per pot and watered as needed. After 4 months (16

Received for publication 15 Oct. 1991. Accepted for publication 23 Oct. 1992. The cost ofpublishing this paper was defrayed in part by the payment of page charges. Under postal regulations, this paper therefore must he hereby marked advertisement solely to indicate this fact.

'Professor of Horticulture.

${ }^{2}$ Associate Professor of Horticulture.

${ }^{3}$ Former Research Technician.
Nov. 1990), each potted plant was sprayed to drip with aqueous BA at $0,100,200,300$, or $400 \mathrm{mg} \cdot$ liter $^{-1}$. Control plants were sprayed with tap water. Each treatment was replicated 12 times; one pot equaled one replication. The pots were arranged in a split-plot design; cultivars were main plots and the five BA treatments were subplots.

Cumulative shoot emergence was recorded every other day, 10 to 35 days after treatment application, after which freezing temperatures killed the new shoots and ferns. Data were analyzed by analysis of variance.

BA promoted shoot emergence in all cultivars (Table 1). The control plants produced few shoots. All tested BA concentrations, which represented a narrow dosage range, elicited similar shoot emergence responses. Except at 18 days after treatment, there was a significant cultivar effect on shoot production; 'UC $157 \mathrm{~F}_{1}$ ' produced fewer shoots than 'Mary Washington' or 'UC $157 \mathrm{~F}_{2}$ '.

Table 1. Effect of BA sprays on subsequent shoot emergence of asparagus seedlings from 26 Nov. to 21 Dec. 1990 (10 to 35 days after spraying).

\begin{tabular}{|c|c|c|c|c|c|}
\hline \multirow[b]{3}{*}{ Cultivar } & \multirow{3}{*}{$\begin{array}{c}\text { BA } \\
\left(\mathrm{mg}^{\prime} \text { liter }^{-1}\right) \\
\end{array}$} & \multicolumn{4}{|c|}{ Cumulative shoots per plant (no.) } \\
\hline & & \multicolumn{4}{|c|}{ Days after spraying } \\
\hline & & 10 & 18 & 28 & 35 \\
\hline \multirow[t]{5}{*}{$\overline{\text { Mary Washington }}$} & 0 & 0.0 & 0.0 & 0.4 & 0.5 \\
\hline & 100 & 0.0 & 2.5 & 5.3 & 9.1 \\
\hline & 200 & 0.1 & 4.5 & 8.8 & 13.7 \\
\hline & 300 & 0.3 & 2.3 & 4.7 & 7.8 \\
\hline & 400 & 0.7 & 3.8 & 6.9 & 11.9 \\
\hline \multirow[t]{5}{*}{ UC $157 \mathrm{~F}_{1}$} & 0 & 0.0 & 0.1 & 0.5 & 0.8 \\
\hline & 100 & 0.1 & 3.1 & 5.3 & 8.3 \\
\hline & 200 & 0.3 & 2.8 & 5.1 & 9.3 \\
\hline & 300 & 0.0 & 1.8 & 3.7 & 7.6 \\
\hline & 400 & 0.8 & 2.2 & 3.9 & 7.2 \\
\hline \multirow[t]{5}{*}{$\mathrm{UC} 157 \mathrm{~F}_{2}$} & 0 & 0.0 & 0.3 & 0.7 & 0.8 \\
\hline & 100 & 0.0 & 2.7 & 5.6 & 10.1 \\
\hline & 200 & 0.3 & 3.2 & 5.8 & 10.3 \\
\hline & 300 & 1.1 & 4.5 & 6.3 & 9.5 \\
\hline & 400 & 2.9 & 4.5 & 6.9 & 10.2 \\
\hline \multicolumn{6}{|l|}{ Analysis of variance } \\
\hline Treatment (T) & & $* * *$ & $* * *$ & $* * *$ & $* * *$ \\
\hline Cultivar (C) & & $*$ & NS & * & * \\
\hline $\mathrm{T} \times \mathrm{C}$ & & $* *$ & NS & NS & NS \\
\hline
\end{tabular}

${ }_{\mathrm{Ns}, *, * *, * * *}$ Nonsignificant or significant at $P \leq 0.05,0.01$, or 0.001 , respectively. 